Published by LPMP Imperium

Journal homepage: https:/ / ejournal.imperiuminstitute.org/index.php/ BERDAYA

\title{
Pelatihan Dan Pengembangan U saha Bagi Kelompok Kuliner D i Desa Waipirit Kabupaten Seram Bagian Barat (SBB) Provinsi Maluku
}

\section{Novalien Lewaherilla, Conchita Valentina, Selfiena Siahainenia, Terezia Pattimahu}

Fakultas Ekonomi dan Bisnis, Universitas Pattimura Ambon

\begin{abstract}
The growth of small businesses is quite significant in Indonesia. Small businesses become the foundation for the development of the economic sector. But often many small businesses encounter problems and obstacles in terms of business management and development. The culinary business in Wal pirit Village, Kairatu Subdistrict, W est Seram Regency (SBB) of $M$ aluku Province in their development also encountered obstacles and problems, so this business did not show any significant development from the beginning.

The objectives of this community service activity are: (1) providing an understanding of business management, (2) conducting financial management training and simple bookkeeping. (3) conduct training on promotion more aggressively and openly, (4) conduct training on responsiveness to serve consumers.W ith this activity, it is expected that the behavior and business strategies of the Culinary G roup mothers will change, so that in the future the business can be more advanced and the family's economic income will increase
\end{abstract}

Keywords

Training and Business Development, Culinary Groups
BERDAYA : Jurnal Pendidikan dan Pengabdian Kepada M asyarakat

Vol 2, N 0.1, A pril 2020, pp. 1-8 elSSN 2721-6381

\section{Article History}

Received 8 Mar 2020 / Revised 23 Mar 2020/ A ccepted 25 Apr 2020 / First Published: 30 A pr 2020

\section{To cite this article}

Novalien Lewaherilla, Conchita Valentina, Selfiena Siahainenia, \& Terezia Pattimahu. (2020). Pelatihan Dan Pengembangan Usaha Bagi Kelompok Kuliner Di Desa Waipirit Kabupaten Seram Bagian Barat (SBB) Provinsi Maluku. BERDAYA: Jurnal Pendidikan dan Pengabdian Kepada M asyarakat,2(1), 1-8

DOI:

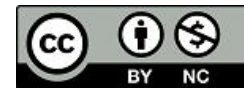

(C) 2020. This open access article is distributed under a Creative Commons Attribution (CC-BY-NC) 4.0 license 


\begin{abstract}
ABSTRAK
Pertumbuhan usaha kecil cukup signifikan di Indonesia. U saha kecil menjadi fondasi bagi pengembangan sektor ekonomi. Tetapi seringkali banyak usaha kecil menemui masalah dan kendala dalam hal pengelolaan dan pengembangan usaha. U saha kuliner yang berkembang di D esa Wal pirit Kecamatan Kairatu Kabu paten Seram Bagian Barat (SBB) Provinsi M aluku dalam perkembangannya juga menemui kendala dan masalah, sehingga usaha ini tidak memperlihatkan perkembangan yang berarti sejak awal.

Tujuan dari kegiatan pengabdian masyarakat ini adalah : (1) M emberikan pemahaman tentang Pengelolaan U saha, (2) Melakukan Pelatihan pengelolaan keuangan dan pembukuan sederhana. (3) Melakukan pelatihan tentang Promosi secara lebih gencar dan terbuka, (4) M elakukan pelatihan tentang ketanggapan melayani konsumen. D engan adanya kegiatan ini, diharapkan perilaku dan strategi usaha dari Ibu-ibu kelompok Kuliner ini mengalami perubahan, sehingga kedepan usaha bisa lebih maju dan pendapatan ekonomi keluarga menjadi bertambah
\end{abstract}

Kata Kunci : Pelatihan dan Pengembangan Usaha, Kelompok Kuliner
Profil Penulis

Novalien Lewaherilla

Conchita Valentina

Selfiena Siahainenia

Terezia Pattimahu

Fakultas Ekonomi dan Bisnis, Universitas Pattimura Jl. Ir. M. Putuhena, Poka, Tlk. Ambon, Kota Ambon, Maluku

Penulis Korespondensi: Novalien Lewaherilla email: novalewaherilla@yahoo.com

Reviewing Editor

Suryani, IAIN Lhokseumawe

\section{PENDAHULUAN}

Desa Waipirit yang berada di Kabupaten Seram Bagian Barat, Provinsi Maluku merupakan salah satu desa dimana terdapat kelompok ibu-ibu yang tergabung dalam usaha penjualan kuliner yakni keripik pisang, Usaha ini sudah ada sejak dioperasikannya pelabuhan angkutan laut yaitu Dermaga Feri yang beroperasi melayani jalur penyeberangan laut antara pulau Seram dengan pulau A mbon. Usaha kuliner makanan ringan (camilan) di desa Waipirityang dijalani oleh ibuibu ini sebanyak 50 orang dan dirintis dengan menggunakan ketrampilan seadanyadengan mengolah sumber daya alam yang tersedia.Seperti diketahui bahwa potensi sumber daya alam yang terbesar di Maluku dari 14 jenis komoditi buah-buah unggulan lainnya adalah buah Pisang yang jumlah produksinya mencapai 23.573 ton pada tahun 2017 (Maluku Dalam Angka, 2018, terdapat pada kabupaten Seram Bagian Barat. Dengan demikian, sangatlah tepat jika sumber daya alam ini dapat dikelola untuk menghasilkan sumber pendapatan, termasuk melalui usaha kuliner ini.

Tujuan utama usaha kuliner ini dijalankan adalah untuk menambah pendapatan dan meningkatkan perekonomian keluarga. Jenis makanan ringan yang dijual adalah keripik pisang, keripik keladi, dan keripik lainnya. Namun, manajemen usaha dari kelompok usaha kuliner ini masih terbatas mulai dari pengolahan hingga pemasarannya. Penjualan hanya terbatas di kios depan dermaga Fery dan juga diatas kapal Fery yang sementara berlabuh. Target pembeli hanya pada masyarakatyang mengunjungi kota kabupaten dan daerah-daerah wisata di pulau Seram dan pengunjung yang menggunakan kapal Fery.

Dalam upaya meningkatkan perkembangan dan pertumbuhan usaha kecil, maka langkah awal adalah mempelajari karakteristik serta permasalahan yang dihadapi oleh UMKM ( Winardi, 2006). Persoalan dan masalah yang dihadapi oleh kelompok usaha kuliner ini adalah kurangnya pengetahuan tentang bagaimana mengelola usaha secara baik, terutama manajemen pemasaran, dimana perlunya metode promosi yang lebih baik untuk menjangkau pasar yang lebih luas, Selain itu atribut produk yang belum memadai yakni kemasan yang masih sangat tradisonal. Terbatasnya kemampuan mengelola keuangan secara baik menjadi hambatan yang sulit untuk 
diatasi, padahal sumber- sumber modal sudah tersedia lewat perbankan dan lembaga keungan lainnya yang memungkinkan usaha kecil ini dapat berkembang.

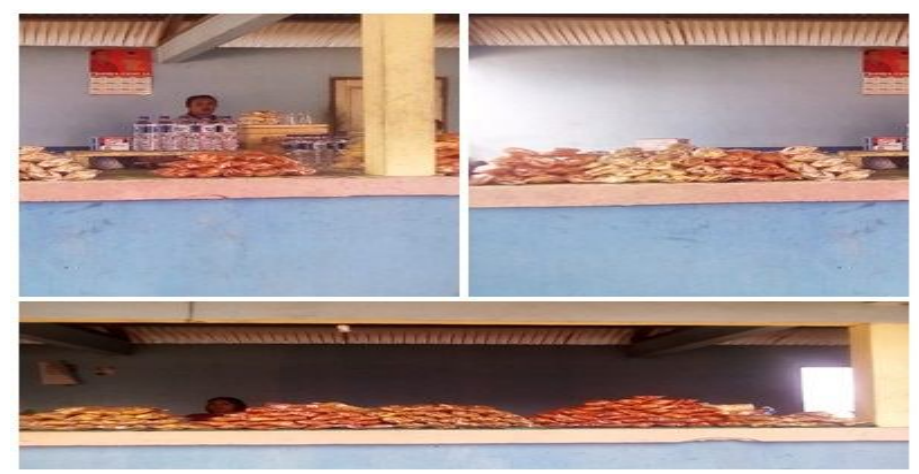

Gambar 1. Aktivitas Penjualan Kripik di Dermaga Waipirit

Sumber: dokumentasi tim peneliti

Meskipun penuh dengan keterbatasan, tetapi keinginan dan harapan sederhana dalam diri mereka, membuat mereka gigih untuk memproduksi dan memasarkan produk makanan ringan ini, untuk menambah pendapatan keluarga, terutama komsumsi rumah tangga dan biaya pendidikan anak
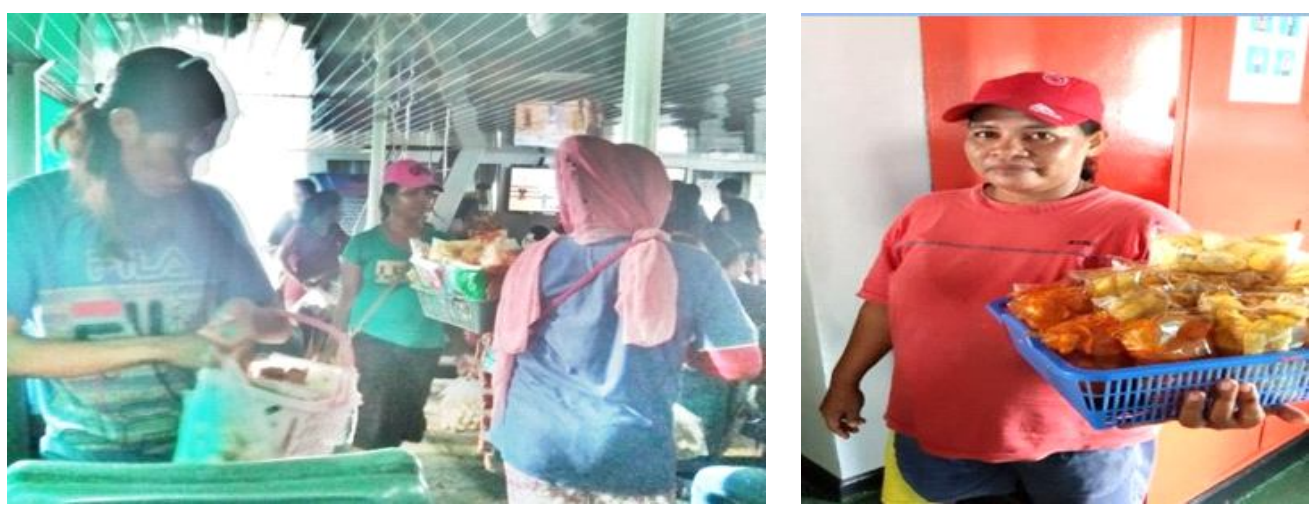

Gambar 2. Aktifitas Penjualan Kripik di Kapal Fery Sumber: dokumentasi tim peneliti

\section{Persoalan Mitra}

Persoalan utama yang dihadapi usaha kuliner ini terkait pengembangan jiwa entrepreneurship yang dimiliki. Jiwa entrepreneurship yang dikembangkan akan mendorong mereka untuk belajar dan membangun jaringan kerja yang luas, sehingga usaha semakin maju dan luas. Betapa pentingnya pelatihan dan pengembangan usaha baik yang dilakukan oleh pemerintah atau pihak terkait lainnya. Menurut Hafsah, 2004 dalam Alhempi, Raden (2013) bahwa upaya untuk pengembangan usaha kecil merupakan tanggung jawab bersama antara pihak pemerintah dan masyarakat.

Berdasarkan analisis situasi yang telah dipaparkan, maka dapat dilihat bahwa masalah yang dihadapi oleh kelompok usaha kuliner dan penganan ringan ini adalah:

1. Kurangnya pemahaman tentang pengel ol aan usaha secara baik

2. Pemasaran dan promosi produk masih terbatas

3. Kelompok usaha kuliner belum melakukan pencatatan keuangan usaha dengan tepat .

4. Masih minim pemahaman tentang pelayaanan yang memuaskan kepada pelanggan 
Tujuan Dari kegiatan pelatihan ini adalah :

1. Memberikan pemahaman tentang Pengelolaan Usaha secara baik, terutama untuk mengembangkan kualitas produk dan kemasan, manajemen pemasaran dan penjualan.

2. Melakukan pemahaman dan pelatihan tentang Promosi secara lebih gencar dan terbuka

3. Melakukan pemahaman dan pelatihan pengelolaan keuangan dan pembukuan sederhana.

4. Memberikan pemahaman dan pelatihan tentang ketanggapan melayani konsumen

\section{Tahapan Pelaksanaan}

\section{MATERI DAN METODE}

Adapun kegiatan awal dimulai dengan studi lapangan, untuk melihat dan meninjau keadaan kelompok usaha kuliner dan makanan ringan di desa Waipirit Kecamatan Kairatu, Kabupaten Seram Bagian Barat, Provinsi Maluku terutama aktivitas ibu- ibu pelaku usaha serta mengidentifikasikan masalah yang sering terjadi pada kelompok usaha ini. Sosialisasi dan pendekatan awal dengan Kelompok usaha, kepala Desa dan Dinas Perindustrian Kabupaten Seram Bagian Barat.Sosialisasi awal dilakukan dengan kepala desa dan kelompok usaha , tentang tujuan kegiatan yang ingin dilaksanakan. Tahapan selanjutnya adalah tahapan pelatihandan pengembangan bagi kelompok usaha kuliner.

\section{Materi Pelatihan}

Pemberian Materi dan Pelatihan yang dikelompokkan menjadi empat bagian, yaitu:

- Materi I. Stretegi Pengelolaan Usaha

- Materi 2. Srategi pemasaran dan Promosi

- Materi 3. Cara Pembuatan Pembukuan Sederhana

- Materi 4. Teknik Pelayanan Yang Memuaskan Pelanggan

Diskusi berkelompok

Diskusi dengan ibu- ibu kelompok usaha untuk menggali informasi mengenai apa yang dialami dan menjadi masalah dalam pengembangan usaha kuliner dan penganan ringan. Dengan diskusi, maka ada solusi yang ditawarkan. Dalam kelompok juga ada praktek Pembuatan Pembukuan Sederhana

\section{Evaluasi Kegiatan}

Setelah proses pelaksanaan diadakan evaluasi untuk melihat apakah pelatihan yang diberikan memiliki indikator keberhasilan. Setelah proses pelaksanaan diadakan evaluasi untuk melihat apakah pelatihan yang diberikan memiliki indikator kerberhasilan. Evaluasi yang dilakukan adalah dengan menerima feedback dari yang menjadi mitra kita dan pengunjung yang lewat.

\section{Perencanaan kegiatan}

\section{HASIL DAN PEMBAHASAN}

Pada tanggal 30 -31 Agustus 2019, kegiatan pengabdian kepada masyarakat dilakukan, dan sebagai Nara Sumber dari Fakultas Ekonomi Universitas Pattimura Ambon, kami melakukan persiapan awal dengan Ibu Pejabat Kepala Desa beserta Staff. Pembukaan kegiatan dilakukan oleh Ibu Pejabat Kepada Desa Waipirit Kecamatan Kairatu Kabupaten Seram Bagian Barat (SBB)dan dikuti oleh 50 orang yang adalah ibu-ibu wirausaha kuliner 

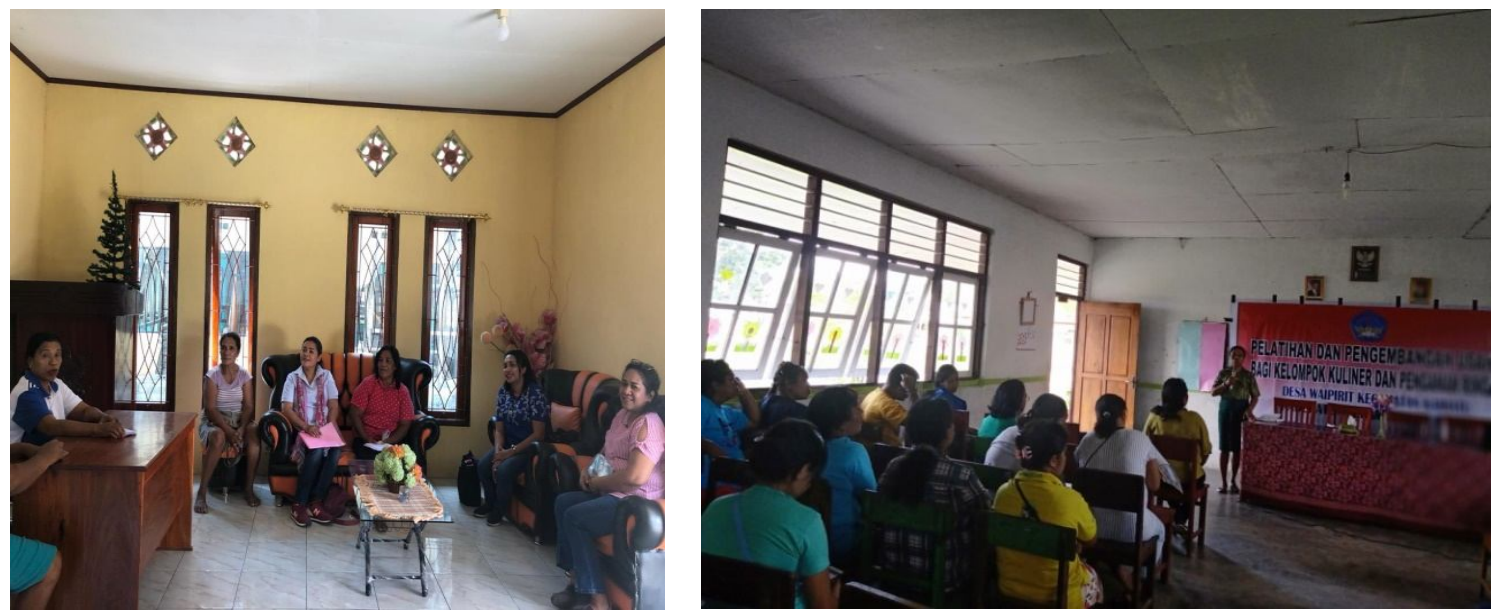

Gambar 3. Sosialisasi Kegiatan di kantor Desa (Kiri), dan Pembukaan Kegiatan oleh Ibu Pejabat Kepala Desa

Sumber: dokumentasi tim peneliti

Materi pertama yang disampaikan antara lain berupa: Karekteristik utama yang harus dimiliki untuk menjadi wirausaha sukses. Pada sesi ini mitra diberikan pemahaman bagaimana tipe seorang wirausaha dan apa yang dimiliki supaya bisa menjadi seorang wirausaha yang sukses. Dimana kareketeristik wirausaha sukses antara lain, berani mengambil resiko, pantang menyerah, ulet dan kerja keras, disiplin tinggi, pandai mengelola waktu, membangun jaringan, rajin membaca, dll. Selain materi disampaikan oleh kami sebagai narasumber, maka mitra pun diajak berpikir dan memberikan sharing pengalaman apa yang sudah dilakukan selama ini, yang menurut mereka hal itu menjadi kunci kesuksesan usaha. Untuk sesi ini juga dilakukan melalui games" Kartu Sukses".

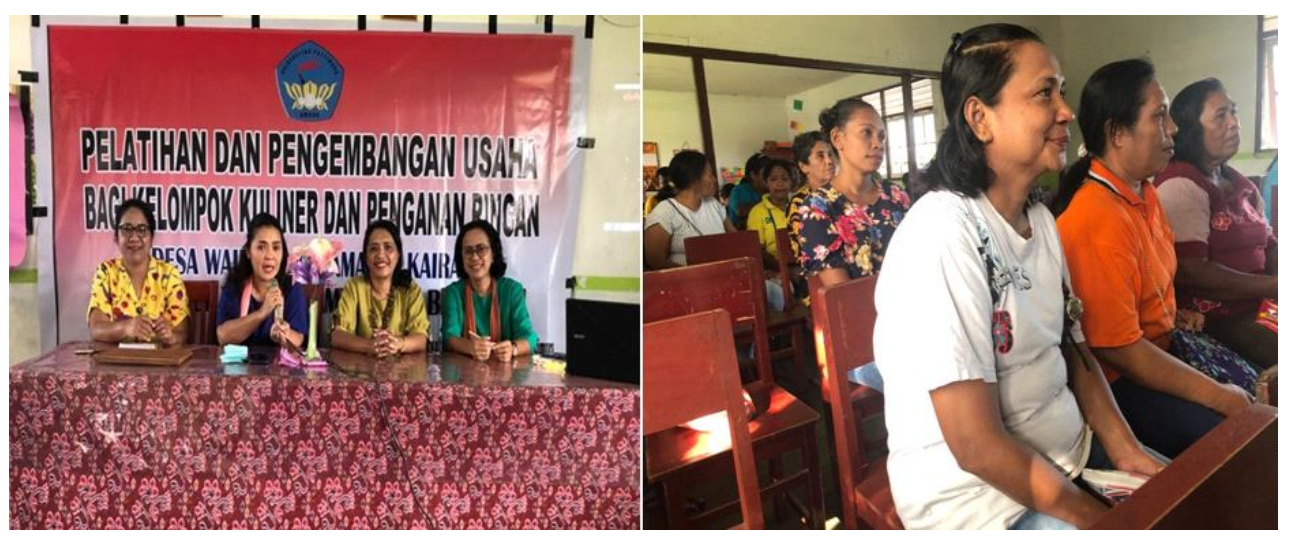

Gambar 4. Pemberian Materi (Kiri), Peserta Pelatihan (Kanan)

Sumber: dokumentasi tim peneliti 

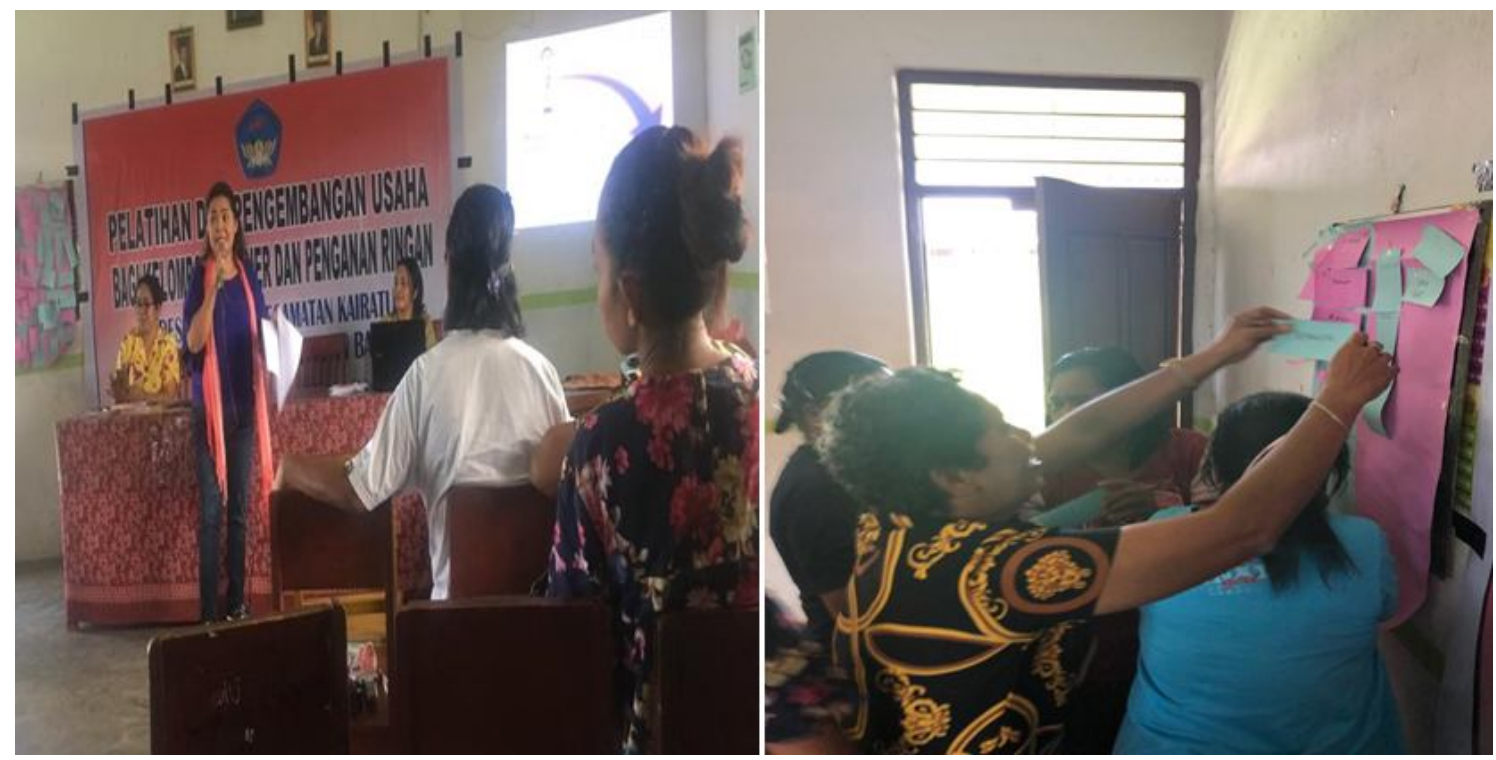

Gambar 5. Pemberian Materi tentang Kunci Sukses Wirausaha oleh Ibu Conchita (Kiri), Peserta terlibat dalam game kartu Sukses

Sumber: dokumentasi tim peneliti

Materi selanjutnya adalah memberikan pemahaman tentang memperluas jaringan pemasaran produk melalui promosi yang gencar. Pada sesi ini mitra dibukakan wawasan berpikir bahwa penjualan produk jangan hanya terbatas pada lokasi sekitar Pelabuhan Waipirit atau di dalam Fery Penyeberangan Waipirit- Hunimua, tetapi harus memperluas usaha seperti menjangkau pasar-pasar lain misalnya swalayan dan toko-toko oleh-oleh di Ambon. Selain itu yang paling penting harus dilakukan adalah memiliki Ijin dari Dinas Kesehatan dan Balai Pom. Selain itu melatih ibu-ibu untuk bagaimana melakukan penetrasi pasar dengan memperluas pasar sasaran, melalui media social yang ada seperti Facebook.

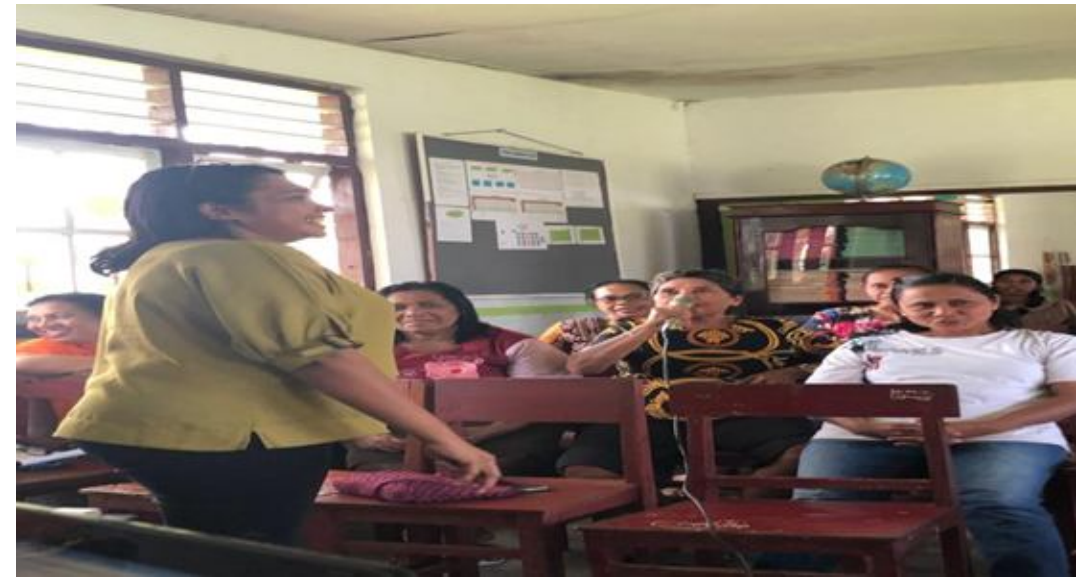

Gambar 6. Pemberian Materi Pengelolaan Usaha oleh Ibu Novalien

Sumber: dokumentasi tim peneliti

Materi selanjutnya adalah pelatihan pembukuan sederhana. Disadari sungguh bahwa mitra masih belum memahami cara membuat pembukuan sederhana. Selain itu ibu-ibu kelompok kuliner ini juga tidak pernah melakukan pencatatan tentang biaya-biaya yang terkait pemasukan dan pengeluaran.Kalaupun mereka melakukan pencatatan, itu juga tidak sistimatis dan tidak pada buku.Dengan demikian, pelatihan membuat pembukuan sederhana ini dirasakan besar manfaatnya oleh ibu-ibu pelaku usaha. 


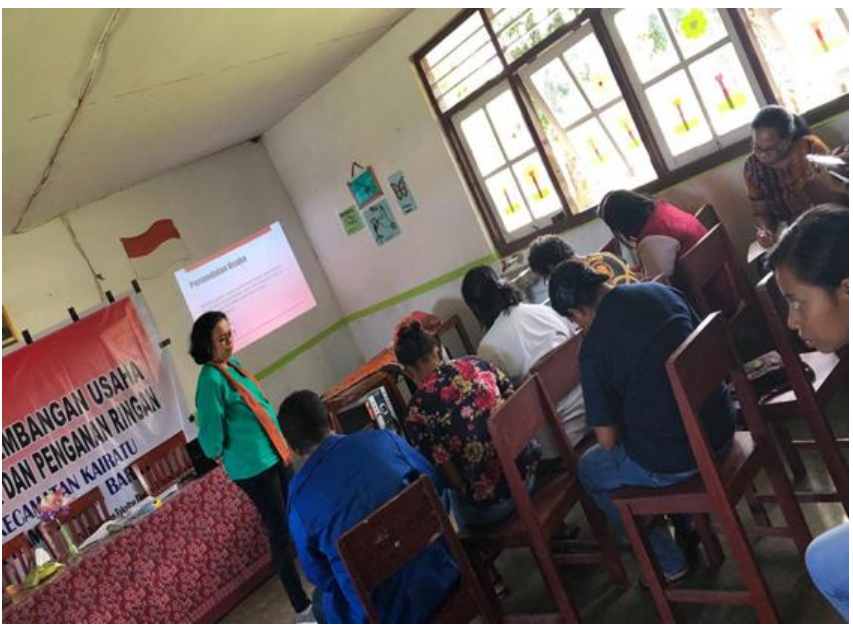

Gambar 7. Pemberian Materi dan Pelatihan Pembukuan Sederhana oleh Ibu Terezia

Sumber: dokumentasi tim peneliti

Materi selanjutnya adalah pelatihan tentang pelayanan yang memuaskan kepada pelanggan. Kebutuhan akan materi ini dirasakan perlu oleh ibu-ibu, sehingga kami memberikan trik-trik secara langsung bagaimana memperlakukan pelanggan secara baik dan meningkatkan kualitas pelayanan secara maksimal. Hal ini sangat bermanfaat bagi ibu-ibu,terutama menyangkut penampilan secara fisik, kebersihan tubuh, tutur kata yang halus (tidak kasar) kepada pelanggan dan respons yang cepat pada kebutuhan pelanggan. Mitrapun merasakan bahwa pelayanan secara maksimal itu sangat penting, demi kepuasan pelanggan dan upaya mempertahankan pelanggan dan meningkatkan volume penjualan

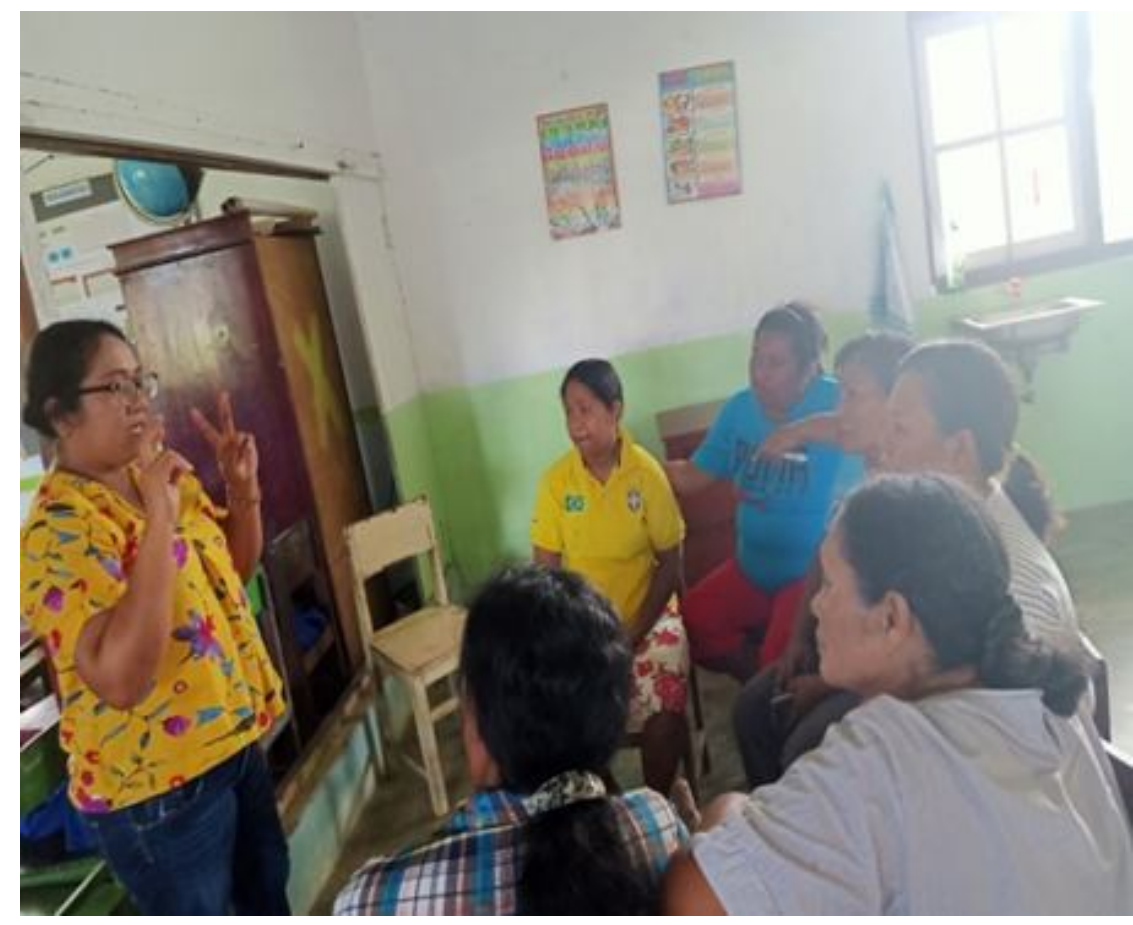

Gambar 8. Pemberian materi “ Teknik Pelayanan Yang Memuaskan" oleh Ibu Selfiena

Sumber: dokumentasi tim peneliti 


\section{KESIMPULAN}

Pelatihan tentang pengelolaan dan pengembangan usaha menjadi sangat penting dan dibutuhkan oleh ibu-ibu pelaku usaha, untuk mengembangkan dan memperluas usahanya. Selain itu, pelatihan juga dapat memperbaiki dan merubah pola pikir wirausaha sehingga tidak hanya bertujuan untuk memenuhi kebutuhan hidup. Dengan kegiatan pengabdian masyarakat yang dilakukan ini, ada banyak manfaat yang diterima oleh ibu-ibu. Antusias dan perhatian serta respons ibu-ibu pelaku usaha sangat baik sekali pada saat dilakukan pelatihan, monitoring dan evaluasi. Kegiatan Pelatihan ini dirasakan sangat bermanfaat dan membawa perubahan yang berarti bagi ibu-ibu pelaku usaha di Desa Waipirit Kecamatan Kairatu Kabupaten Seram Bagian Barat (SBB).

\section{Saran Lanjutan}

Kegiatan - kegiatan pelatihan usaha seperti ini harus terus dikembangkan dan berkesinambungan bagi ibu-ibu kelompok usaha kuliner dan penganan ringan di desa Waipirit Kecamatan Kairatu Kabupaten Seram Bagian Barat (SBB). Selain itu, perlu juga adanya pendampingan dari dinas-dinas terkait untuk mengembangkan kelompok usaha dan pemberian bantuan financial sebagai dorongan dan motivasi untuk memperluas bidang usaha.

\section{UCAPAN TERIMA KASIH}

Tim Pengabdian dari Dosen Fakultas Ekonomi Universitas Pattimura Ambon mengucapkan banyak terima kasih kepada pihak LPPPM (Lembaga Penelitian dan Pengabdian Pada Masyarakat) Universitas Pattimura yang telah mendukung dalam hal financial. Terima kasih juga kepada Ibu Pejabat kepala Desa beserta Staff yang memberikan kesempatan untuk tim melakukan kegiatan ini, terutama kepada ibu-ibu kelompok usaha kuliner yang bersedia dilatih oleh Tim Pengabdian, sehingga kegiatan ini telah selesal dilakukan dengan baik

\section{REFERENSI}

Alhempi, R. R., \& Harianto, W. (2013). Pengaruh Pelatihan dan Pembinaan Terhadap Pengembangan U saha Kecil Pada Program Kemitraan Bina Lingkungan. Faculty of Business and Economics, Trisakti University.

Badan Pusat Statistik Maluku. (2018). Maluku Dalam Angka. Maluku: BPS Provinsi

Winarni, E. S. (2006). Strategi pengembangan usaha kecil melalui peningkatan aksesibilitas kredit perbankan. Infokop nomor, 29, 92-98.

\section{FUNDING}

Kegiatan ini merupakan bagian dari program Pengabdian Kepada Masyarakat yang didanai oleh DIPA Universitas Pattimura tahun 2019

\section{COM PETIN G INTERESTS}

Tidak ada konflik kepentingan untuk diungkapkan. 